\title{
Competitive Advantage as Relationship Mediation between Supply Chain Integration and Fishery Company Performance In Southeast Sulawesi (Indonesia)
}

\author{
La Hatani ${ }^{1}$, Djumilah Zain and Djumahir ${ }^{2}$, Budisantoso Wirjodirjo ${ }^{3}$ \\ ${ }^{I}$ (Department of Management, Haluoleo University, Southeast Sulawesi of Indonesia) \\ ${ }^{2}$ (Department of Management, Brawijaya University, Malang East Java of Indonesia) \\ ${ }_{3}^{3}$ (Department Of Industrial Engineering, Institute Of Technology Sepuluh November, Surabaya of Indonesia)
}

\begin{abstract}
This research aims to test and explain the role of competitive advantage as mediator for the relation between supply chain integration and company performance. The design of this research is survey and data was collected as cross-section using questionnaire. The unit of analysis is big-scale fishery companies. The respondents this research is the managers of fishery company. The result of this research shows that integrated internal supply chain implementation can improve competitiveness and performance of the company. External integration supply chain can improve competitiveness, but without any real impact on company performance. High level of competitiveness can improve company performance. High level of competitiveness is also found to be a mediator for the relation of supply chain integration on company performance. Lastly, the impact of seasonal variation is one of the reason for the low competitiveness of company performance. The practical implication of this study is providing knowledge and information for managers in improving the company's competitive advantage and performance through the implementation of internal and external of supply chain integration. Then consideration of season factor can be used as input in anticipating the needs of fish supply so that the production process remains running smooth.
\end{abstract}

Keywords: Competitiveness, Performance, Supply Chain Integration

\section{Introduction}

Supply chain integration continues to be a key theme amongst those seeking to understand how to harness the potential of the supply chain to create sustainable value. Much attention has been given to the implementation of integrative Supply Chain Management (SCM), both from academicians and from practitioners. Some practitioners have realized the importance of SCM implementation, but have not understood how to implement it. This condition is caused by a lack of clarity and consistency in what is to be measured in the implementation of integrative SCM [1]. The theoretical basis for justifying the role of integrative SCM implementation in improving competitiveness and performance of the company is still weak and this has been the cause of many debates [2,3]. It is important to carry out further study in relation to this finding, especially by using a contingency approach where the impact of integration of supply chain on competitiveness and performance is variable from upstream to downstream [1].

Competitive advantage is the core of success or failure for a company. Over the years the attention of practitioners and academic literature on integration practices between supply chain partners has significantly grown [4]. The intensification of global competition and the demand for better customer service have considerably increased the need for integration between companies. Consequently, supply chain integration, aimed at coordinating processes along the supply chain seamlessly, nowadays is considered an important determinant to maintain a competitive advantage over competitors. Competition would determine the appropriateness of the activities carried out by company to support its performance [5]. Numerous studies have explored the concept of supply chain integration in different research areas such as inventory planning and logistics $[3,7,8]$, information processing $[1,6]$ or partnership/relationships $[9,10]$. The dominant belief is that supply chain integration is a useful approach to improve various measures of firm performance $[4,6,11,12]$. However, some authors argue that performance improvements are not assured if supply chain integration programs are not accompanied by the implementation of a coherent mix of supply chain management initiatives encompassing, for instance, lead time reduction, supplier network rationalization, production network reconfiguration, development of partnerships, etc $[2,6,10]$. In particular, it has been proposed that implementing integration both upstream and downstream is better than concentrating the firm's efforts on integrating customers or suppliers only [1,7].

SCM integration is a theory which is based on the idea that effective coordination, cooperation and collaboration can improve competitiveness and in the end would support company performance [14]. Implementation of supply chain management which is integrated both internally and externally has opened a 
strategic opportunity to create competitiveness [15]. Furthermore, some studies have concluded that different dimensions of supply chain integration, e.g. internal integration, external integration (supplier and customer), could contribute to competitive advantage $[7,11]$ and it would also improve firm or company performance $[1,7,10,25]$. Then, good integration of external supply chain would have significant impact on the improvement of competitiveness [7,11] and firm performance [1,16]. However, different from the findings above, [17] finds that internal and external integration of supply chain do not bring about competitive advantage and improvement in performance for small firms [2].

There are gaps in the results of studies in external integration involving supplier, where it is found that it does not have significant impact on company performance [3]. While the external integration involving customers does not significant impact on the performance of delivery [1]. However, some recent studies discovered that the impact of supply chain integration on company performance may not be unconditional. These studies suggest that the performance implications of supply chain integration could be contingent on competitive advantage $[1,18]$. Lack of consistency in the research findings has opened an opportunity for further testing to the relation of external integration of supply chain with company performance. Despite this recognition, SCM literature does not empirically examine the way these integration practices and whether their simultaneous presence can determine a positive additional synergistic effect on companies performance.

Several authors distinguish between integration with customers and suppliers and investigate the main impact of each integration activity on companies' performance [19]. A key question is whether the implementation of supply chain integration can make an impact on competitiveness and company performance both directly and through the mediation of competitiveness? This paper intends to contribute to filling this gap by focusing on efficiency company performance. In particular, the aims to achieve clarity in the midst of debates and contradictions of previous research findings concerning the role of competitiveness as mediator for the implementation of supply chain integration on company performance. The contribution of this research is theoretical enrichment of the literature of operational management, especially supply chain management. In practical terms, this research also contributes to the management of fishery companies in the effort to improve competitiveness and performance of the company and to the knowledge of the factors which requires priority and should be considered important in the implementation of supply chain integration.

\section{Literature Review and Conceptual Model \\ 2.1 Relationship Between of Supply Chain Integration on Competitiveness and Performance}

Supply chain management is an integrative philosophy to manage the total flow of channel from the earliest supplier of raw materials to the ultimate customer and beyond, including the disposal process [20]. Supply chain management is the synchronization of firm processes with those of its suppliers and customers to match the flow of materials, services and information with customer demand [14]. Implementation of supply chain management which is integrated both internally and externally has opened a strategic opportunity to create competitiveness [15]. Integration on supply chain requires an internal integration across the functions in the company and requires external integration with the supplier and customers [1]. The effort to achieve high level of competitiveness and performance in each firm is applied by implementing integrative SCM. In this research, the construct of integrative SCM implementation consist of two variables, that is internal integration and external integration where the measurements are supply chain indicators, that is: cooperation and coordination $[1,7,16]$ and collaboration which is adopted from theoretical review [6,21].

Previous research $[7,11]$ found that a firm which can achieve a high level for implementation of internal integration and external supply chain integration can improve its competitiveness. Supply chain integration involves the processes of collaboration across functional departments, suppliers, and customers to arrive at mutually acceptable outcomes [1,44]. Collaboration is a key element of supply chain integration because strategic collaboration is required to enable cross-functional communication and joint efforts $[6,22,23]$. Supply chain integration is required "internally" within and across functions and "externally" across suppliers and customers $[1,7,12,17,24]$. The integration of all internal functions from materials management to production, sales, and distribution is paramount to meeting customer requirements at the lowest total system cost. Thus, internal integration is characterized by full systems visibility across functions such as procurement, production, logistics, marketing, sales, and distribution [10,16,23,24]. Research finding shows that a company which can achieve high level of implementation for internal integration in the supply chain can improve its competitiveness $[7,11]$ and performance $[1,10,25]$. Based on the theories and arguments from previous research, the first hypothesis proposed here is that good internal integration would have positive and significant impact on competitiveness and performance of the firm, as follows:

$\mathrm{H}_{1 \mathrm{a}}$. Internal integration will be positively associated with competitive advantage

$\mathrm{H}_{1 \mathrm{~b}}$. Internal integration will be positively associated with firm performance.

The external integration of supply chain is an effective coordination between the processes in the supply chain through continuous flow of information, material and cash flow into the supplier and customer [14]. External 
integration is the integration of supply chain and information beyond the boundaries of the firm where external integration can be measured through coordination, cooperation and collaboration with members of the supply chain, that is supplier and customers [7]. That external integration is related to the integration of database application among business partners, that is supplier and consumers [22]. Through external integration, a firm can build cooperation, coordination and coordination for procurement of goods and services for the consumer in an efficient manner [12]. The measurement of construct of external integration in this research is not aimed at evaluating the global level of firm's external integration which would require us to study the integration in all parts of the supply chain, but is more focused on the integration to the supplier and customer. The findings of [3] shows that external integration of supply chain which is an interaction between the integration of supplier and customer can improve firm performance. External integration of supply chain can have significant impact on the competitiveness $[7,11]$ and can improve firm performance $[1,7,16]$.

Several other findings are different from the above, though $[2,17]$ where it is found that external integration cannot bring about competitiveness and does not have significant impact on the competitiveness of small companies. External integration to suppliers does not have significant impact on firm performance [3] while internal integration to customer does not have significant impact on the performance of delivery [1]. External integration extends the scope of information sharing and collaboration to include suppliers and customers $[2,7,11,12,14]$. Lack of consistency among the research findings has opened an opportunity for reexamining the relation between external integration and firm performance. Referring to the implications of research [3], external integration should not separate between integration to supplier and integration to customer so as to prevent differences in perception in understanding the needs of the supplier and customers. Referring to the arguments from the previous studies, then the second hypothesis which is proposed here states that good external integration would have positive and significant impact on competitive advantage and firm performance, as follows:

$\mathrm{H}_{2 \mathrm{a}}$. External integration will be positively associated with competitive advantage

$\mathrm{H}_{2 \mathrm{~b}}$. External integration will be positively associated with firm performance.

\subsection{Relationship Between of Competitive Advantage and Firm Performance}

Competitive advantage or competitiveness is based on the idea that firm performance is influenced by resources and the unique or inimitable capability of the company [26]. The impact of competitiveness on firm performance is examined here based on a theory $[14,15]$ that implementation of SCM in an integrated manner can open strategic opportunity for creating competitiveness and in the end would support company performance. Competitiveness in this research is measured by the following indicators: price/cost, quality, delivery dependability, product innovation, time to market $[2,18,26,27]$. This research has developed these indicators by adding the sixth one, that is the post-sales services for supplier.

Company performance is the accumulation of all work carried out by units in the organization or company [43]. In this research, the performance which is measured here can be defined as the ability of the company in achieving efficiency and effectiveness of the supply-chain activities. The construct of company performance in this research is measured through three indicators adopted from [1,3,7], which includes: cost reduction, stock-out reduction and lead-time reduction. This is supported by the findings from several studies $[7,11,13,18]$ that high level of competitiveness can improve firm performance. However, $[2,27]$ found that there is no significant relation between priority of competitiveness with company performance. This discrepancy in research findings on the relation between competitiveness on company performance may be caused by the low capability of the companies in reducing cost, improving quality and low delivery performance. Based on the theoretical review and previous studies, the fourth hypothesis is proposed as follows:

$\mathrm{H}_{3}$. High level of competitiveness is expected to be able to improve firm performance.

Supply chain management incorporates multiple processes and activities from suppliers to customers. With global competitive pressures, organizations have responded with a variety of business strategies to enhance customer value [5]. SCM integration is a theory which is based on the idea that effective coordination, cooperation and collaboration can improve competitiveness and in the end would support company performance [14]. Theory of SCM integration in this research is applied in this research using contingency perspective in order to test and explains the impact of supply chain integration, on competitiveness and performance of firm on different kinds of critical contingency variables. Contingency perspective requires the researcher to choose a variable which would be specified further on how to implement the integrative SCM which are individually interacting with contingency variables in producing competitiveness and performance of the company [1,42]. The propositions of the literature review proposed [1,42] states that from contingency perspective, competitiveness as a variable of mediation can really influence the relation between internal integration and external integration to supply chain on company performance. Integration of supply chain, both internal and external, can improve firm performance, but through competitiveness [27]. Integration along the supply chain is important for managers and researchers because it is a foundation for improving the performance of the firm and 
a source of competitiveness [28]. Based on the argument from previous research, the following fifth hypothesis is proposed here that competitiveness plays important role as mediator for the relation between supply chain integration and company performance, as follows.

$\mathrm{H}_{4 a}$. Internal integration will be positively associated with firm performance, mediated by competitiveness.

$\mathrm{H}_{4 \mathrm{~b}}$. External integration will be positively associated with firm performance, mediated by competitiveness.

The research is conducted at the company where the fishery resources of raw materials (fish) have unique handling characteristics, and greatly depends on the season so that the level of turbulence in fish obtaining is very high. Season is a regular movement both increases and decreases in a certain period of time associated with recurrent events such as weather or climate [15]. In this study, the control variable is seasonal factor that can be measured through the movement impact caused by the increase and decrease of fish supply quantity, quality and delivery time as the supply of fish from the suppliers as raw materials in production process caused by weather or climate. Based on the explanation above, this research is considered important, given the lack of scientific research on the implementation of supply chain flexibility, internal and external of supply chain integration in order to enhance competitive advantage in an integrated implementation, specifically in fishery companies. Based on the theoretical review and results of previous studies, a summary of the conceptual model and research hypotheses is presented in Figure 1.

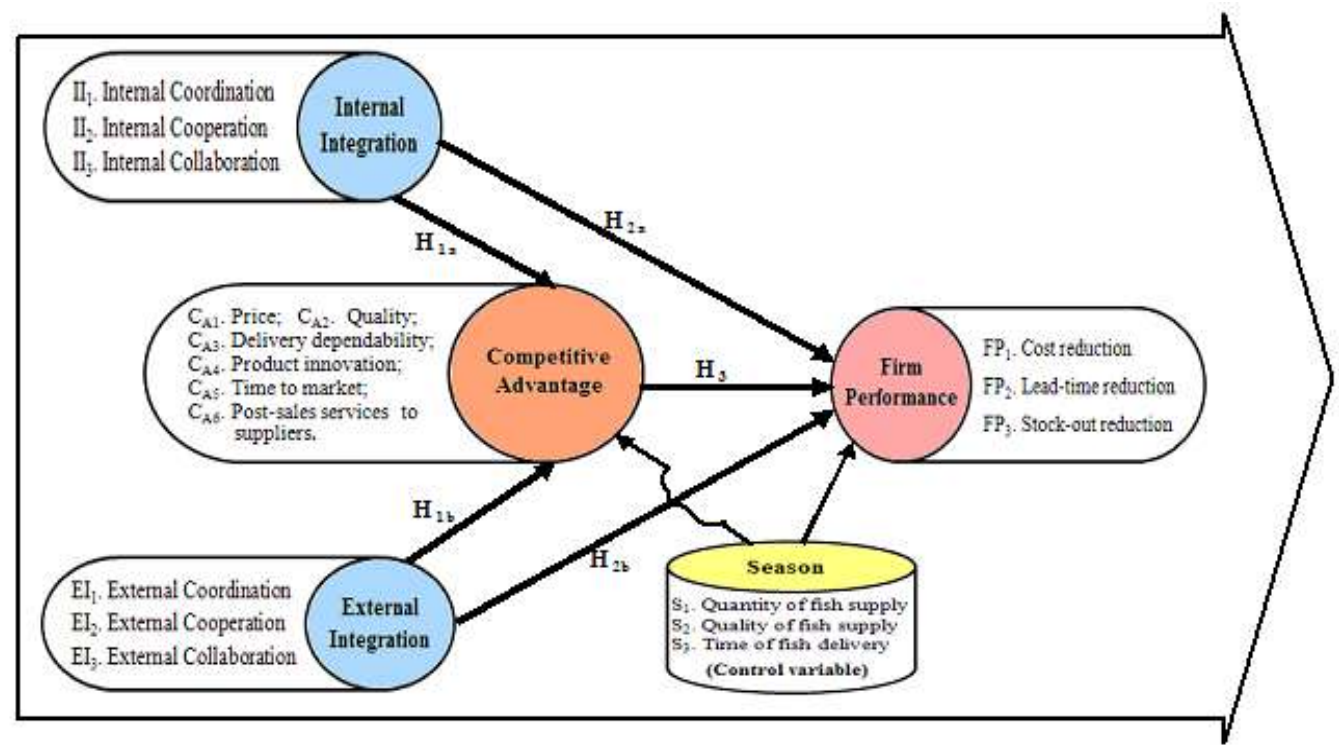

Figure 1. Conceptual model and research hypotheses

\subsection{Population and Sample}

\section{Research Methods}

The design of this research uses explanatory research approach with the aim of making clear the relation between variables through hypothesis testing and making causal conclusion and then followed by choosing among alternatives of Action [29]. The research is conducted in the fishery companies with consideration that fisheries sector as a commodity in Southeast Sulawesi has tried to implement integrated management of fisheries resources from suppliers through to the customer. In addition, potential resource support in Southeast Sulawesi province containing marine resources and fisheries with very big long run hope for Southeast Sulawesi people, especially Indonesia.

Based on the condition in both national level and local level in Southeast Sulawesi, the potential for marine waters which can be exploited in sustainable manner is estimated at 250,000 tonnes annually. The rate of usage until 2010 has only reached 201,412 tonnes, equivalent to IDR 2.34 trillion. The exploitation of this potential has resulted in a sizable contribution to the national and regional development [30]. The irony is that fish processing companies in the province of Southeast Sulawesi in 2010 have managed only to reach a level of production of 22,801.40 tonnes, which is even lower than the 23,011,70 tonnes of 2009. The companies which prioritize on SCM is a new opportunity for the improvement of competitiveness and performance of the company, which should be managed carefully by regulating the chain between organizations [31].

The sample frame was conducted by selecting only the first tier suppliers in fishery companies. We have chosen the fishery companies in Southeast Sulawesi as the population for this study for several reasons. First, the Southeast Sulawesi fishery companies is seen as an indicator of the wealth of an economy [30]. Second, the fishery sector has been a leader in Southeast Sulawesi industry in implementing supply chain 
management strategies. The population for this research is all big scale fishery companies operating in Southeast Sulawesi. The criteria of big scale manufacturing company refers to the rule used by Badan Pusat Statistik (BPS, Central Statistics Agency), that is a company with more than 100 employees. The number of population for bigscale fishery company used as the unit of analysis for this study is 44 companies with 8,924 employees. The distribution of fishery companies is 28 companies in the area of fishery industry (PPS Kendari), 12 companies in the municipality of Bau-Bau and 4 companies in the regency of Buton [32].

Sample was collected using population sampling or census. This technique was chosen with the consideration that the number of population is relatively small, that is 44 companies. The respondents are managers of fishery companies. The consideration for determining these respondents is that directors or managers of a company would have a detailed knowledge on the condition of the firm and the practice of supply chain integration and knowledgeable enough to answer the questions in the survey. The number of respondents for each company is one, that is the person who is positioned in the managerial level, that is director or CEO, production manager or operations manager, logistics manager or quality control manager.

\subsection{Data collection}

Data was collected by a survey which was carried out in its entirety in one stage (one short study) or in a cross-section manner through questionnaire. The distribution of questionnaire to 44 fishery companies in Southeast Sulawesi for the municipalities of Kendari, Bau-Bau and regency of Buton was delivered directly by the researcher. Until the end of the data collection period, the number of questionnaire returned was 42 or equivalent to $95.42 \%$ of the total number of companies in the sample. There are two companies which were difficult to be accessed by the researcher since the management did not allow for research on their company. Therefore the total number of questionnaire for sample and data analysis is the questionnaire from 42 responding companies.

The instrument for this research is questionnaire with closed-ended statements, where the statements are made in such a way that respondents' response is limited to several options. Questionnaire was distributed by direct visit to the company premises to explain the purpose of the questionnaire and require for answer concerning when the filled questionnaire can be retrieved from the company. This is followed by in-depth interview, which is carried out to support and discover the facts behind the findings from quantitative analysis. Interviews were carried out by the researcher after analyzing the data from some of respondents which were considered to be able to provide explanations on the substance of this research.

\subsection{Method of Data Analysis and Measures}

The method for data analysis in this research is Generalized Structured Component Analysis (GSCA). GSCA was developed by [33] as a replacement of factor with linear combination from indicators (manifest variables) in SEM. GSCA analysis uses the least square method in the process of parameter estimation. GSCA is a component-based SEM method which can be used for calculating scores and allows for very small samples [33,34]. GSCA application allows for multi collinearity, that is strong correlation among exogenous variables [33]. The reasons for choosing GSCA in this research are: (1) the model formed at conceptual framework has hierarchical causal relation, that is integrative SCM and supply chain flexibility, which have an impact on competitiveness and then have an impact on performance. Due to the hierarchy, a structural model would be quite useful here; (2) this study uses latent variable which is measured through indicators and GSCA would be appropriate here for confirming the uni-dimensionality of the various indicators for latent variable; (3) GSCA is a powerful method of analysis which does not require much assumption and allows for analyzing a set of latent variables simultaneously; (4) the GSCA method is easier to run since it does not require index modification and GSCA is appropriate for generalizing from relatively small sample.

Data measurement of all variables of this research uses the Likert scale with 5 points, ranging from $1=$ very low/unfavorable to $5=$ very high/favorable $[35,36]$. Given the lack in the SCM literature of a standard scale for measuring internal and external (supplier and customer), competitive advantage, season and firm performance (within and beyond focal firms' boundaries), firstly we identified the central dimensions of integration competitive advantage, season and firm performance usually mentioned in the literature. Then, we followed established guidelines for scale development and examined the measurement model through exploratory methods [37]. Each construct with its block of items was first factor analyzed. This was done to assure the internal rule of uni-dimensionality. Table 1 reports the items comprising each construct, and the outputs of GSCA obtained by factor analyzing the items of each construct separately, along with reliability test results using alpha. Convergent validity is demonstrated since, for each construct only one component with AVE (average variance extracted) the variance explained is above 50 percent and factor loadings are all above 0.70 [33,37]. Then, as suggested by [33], AVE value of all latent variables is greater than 0.50 it can be said to construct or latent variable has good diskriminan validity. Finally, the value of entire construct derived alpha is greater than 0.70 , means that all latent variables have a good composite reliability. 


\subsection{Analysis Result and Evaluation of GSCA Model \\ IV. Analysis and Results}

The model for a research is a representation of a real system, in the sense that it is a simplification or abstraction from the real world or from the phenomenon or complex problem. Evaluation on the GSCA model in this research is started by a measure of fit on the measurement model, which aims to test whether the research instrument is valid or reliable in explaining or reflecting the latent variables. The study begins with a description of variables analysis that aims to interpret the meaning of each variable based on the mean value of research respondents. Based on the evaluation of this research model, it begins with the measure of fit as measurement model that aims to examine (test) whether the research instruments are valid or reliable as research tool in explaining or reflecting latent variables. The test results mean, estimate loading, AVE and alpha of each variable indicator, are presented in Table 1.

Table 1. Loadings, AVE and Alpha

\begin{tabular}{|c|c|c|c|c|c|c|c|}
\hline \multirow[t]{2}{*}{ Constructs } & \multirow[t]{2}{*}{ Indicators } & \multirow[t]{2}{*}{ Mean } & \multicolumn{3}{|c|}{ Loading } & \multirow[t]{2}{*}{ AVE } & \multirow[t]{2}{*}{ Alpha } \\
\hline & & & $\begin{array}{c}\text { Estimat } \\
\mathrm{e}\end{array}$ & SE & $\mathrm{CR}$ & & \\
\hline \multirow[t]{3}{*}{ Internal Integration } & $\mathrm{II}_{1}$. Internal Coordination & 3.71 & 0.920 & 0.038 & $24.03^{*}$ & \multirow[t]{3}{*}{0.837} & \multirow[t]{3}{*}{0.898} \\
\hline & $\mathrm{II}_{2}$. Internal Cooperation & 3.68 & 0.909 & 0.038 & $23.75^{*}$ & & \\
\hline & $\mathrm{II}_{3}$. Internal Collaboration & 3.81 & 0.916 & 0.041 & $22.58^{*}$ & & \\
\hline \multirow[t]{3}{*}{ External Integration } & $\mathrm{EI}_{1 .}$ External Coordination & 3.70 & 0.914 & 0.027 & $33.76^{*}$ & \multirow[t]{3}{*}{0.808} & \multirow[t]{3}{*}{0.877} \\
\hline & $\mathrm{EI}_{2 .}$ External Cooperation & 3.77 & 0.889 & 0.052 & $17.11^{*}$ & & \\
\hline & $\mathrm{EI}_{3}$. External Collaboration & 3.62 & 0.893 & 0.054 & $16.45^{*}$ & & \\
\hline \multirow[t]{6}{*}{ Competitive Advantage } & $\mathrm{CA}_{1}$. Pricing & 3.90 & 0.842 & 0.059 & $14.27^{*}$ & \multirow[t]{6}{*}{0.671} & \multirow[t]{6}{*}{0.901} \\
\hline & $\mathrm{CA}_{2}$. Production quality & 3.95 & 0.859 & 0.039 & $22.24^{*}$ & & \\
\hline & $\mathrm{CA}_{3}$. Reliability & 3.26 & 0.884 & 0.051 & $17.29^{*}$ & & \\
\hline & $\mathrm{CA}_{4}$. Product innovation & 3.36 & 0.810 & 0.066 & $12.36^{*}$ & & \\
\hline & $\mathrm{CA}_{5}$. Time to market & 3.76 & 0.741 & 0.070 & $10.66^{*}$ & & \\
\hline & $\mathrm{CA}_{6}$. Post-sales services & 3.57 & 0.768 & 0.090 & $8.58^{*}$ & & \\
\hline \multirow[t]{3}{*}{ Firm Performance } & $\mathrm{FP}_{1}$. Cost reduction & 3.78 & 0.890 & 0.038 & $23.56^{*}$ & \multirow[t]{3}{*}{0.786} & \multirow[t]{3}{*}{0.862} \\
\hline & $\mathrm{FP}_{2}$. Lead-time reduction & 3.73 & 0.867 & 0.054 & $15.91^{*}$ & & \\
\hline & $\mathrm{FP}_{3}$. Stock-out reduction & 3.70 & 0.902 & 0.047 & $19.11^{*}$ & & \\
\hline Season & $S_{1}$. Quantity of fish supply & 3.38 & 0.981 & 0.005 & $187.35^{*}$ & \multirow[t]{3}{*}{0.950} & \multirow{3}{*}{0.974} \\
\hline \multirow[t]{2}{*}{ (Control variable) } & $S_{2}$. Quality of fish supply & 3.31 & 0.963 & 0.008 & $119.21^{*}$ & & \\
\hline & $\mathrm{S}_{3}$. Time of fish delivery & 3.55 & 0.980 & 0.006 & $171.79^{*}$ & & \\
\hline
\end{tabular}

Note: $\mathrm{CR}^{*}=$ significant at $\alpha=0.05 ; \mathrm{AVE}>.050$; and alpha $>.70$.

The results of the analysis of the description of respondents who indicate the mean value referred in Table 1 that the implementation of internal and external of integration supply chain, competitive advantage, firm performance and season can be concluded that the average of the respondents is quite good or at the level of neutral. This condition occurs because of the reality that there is a statement by the respondent conveying that in the implementation of supply chain flexibility, internal and external of integration supply chain and competitive advantage, there are some companies that are less good in creating coordination, cooperation and internal crossfunctional or external collaboration with suppliers and customers to anticipate uncertainty of supply, quality of production, distribution channel of fish supply, changes in customers' demand and effort to improve the fish supply quality that hamper the company's production process. Some companies are reluctant in sharing the knowledge in the implementation of internal integration, while external integration of suppliers and customers some respondents have mutual suspicion, lack of trust and lack of transparency of information between suppliers and customers of the company. In addition, they do not have any professional human resources, good infrastructure in realizing information technology to fulfill fish supply needs, quality and customer demand changes. There are still some companies that have not applied product delivery through information technology. The companies still use the old ways in doing product delivery. Delivery capability is still low because of inadequate infrastructure support other than because of bad weather (season), because most of the fish delivery to customers via sea transport (ship) that indicates the company is often too late in delivery process of finished products. The evaluation results of the respondents on competitive advantage found at medium level since the implementation of coordination, cooperation and collaboration, there are some respondents say that it is still not good with all business partners so it gives impact on the production flow and less producing a superior product. Besides that, it is due to the lack of understanding and agreement that high flexibility of the supply chain between business partners and companies to improve the smoothness of production process. Ability of supply chain partners to respond market change determines significantly the competitive advantage and performance. The measurement model for all latent variable in Table 1 shows that the estimate for the loading of all indicator variables is higher than $0.70[33,34]$ and the value of CR is significant at confidence of $95 \%(\alpha=.05)$. This 
shows that correlation of all indicator variables are positive and significant and therefore valid for reflecting the measurement of latent variables. As evident from the critical value (CR), all indicator variables can be used for measuring latent variables since the $\mathrm{CR}$ value is significant at $\alpha=0.05$. Average variance extracted (AVE) for all latent variable is greater than 0.50 [34] and therefore the latent construct or variable has diskriminan validity. Therefore, the research instruments which have been used for measuring all latent variables have fulfilled the criteria of diskriminan validity. Then the values of alpha for all constructs is greater than 0.70 , meaning that all latent variables have adequate composite reliability. It is therefore concluded that the research instruments in the measurement have fulfilled the criteria or have high level of fit and reliability.

Evaluation on the structural model is carried out after the relation model is formulated based on the data from observation and on the goodness of fit for the overall model. The structural model is tested in order to determine the relation between latent variables in this research. The result of the tests on the impact among variables is evident from the value of path coefficient and critical value (CR*) which should be significant at $\alpha=$ 0.05 . This is shown in the path diagram in Figure 2 .

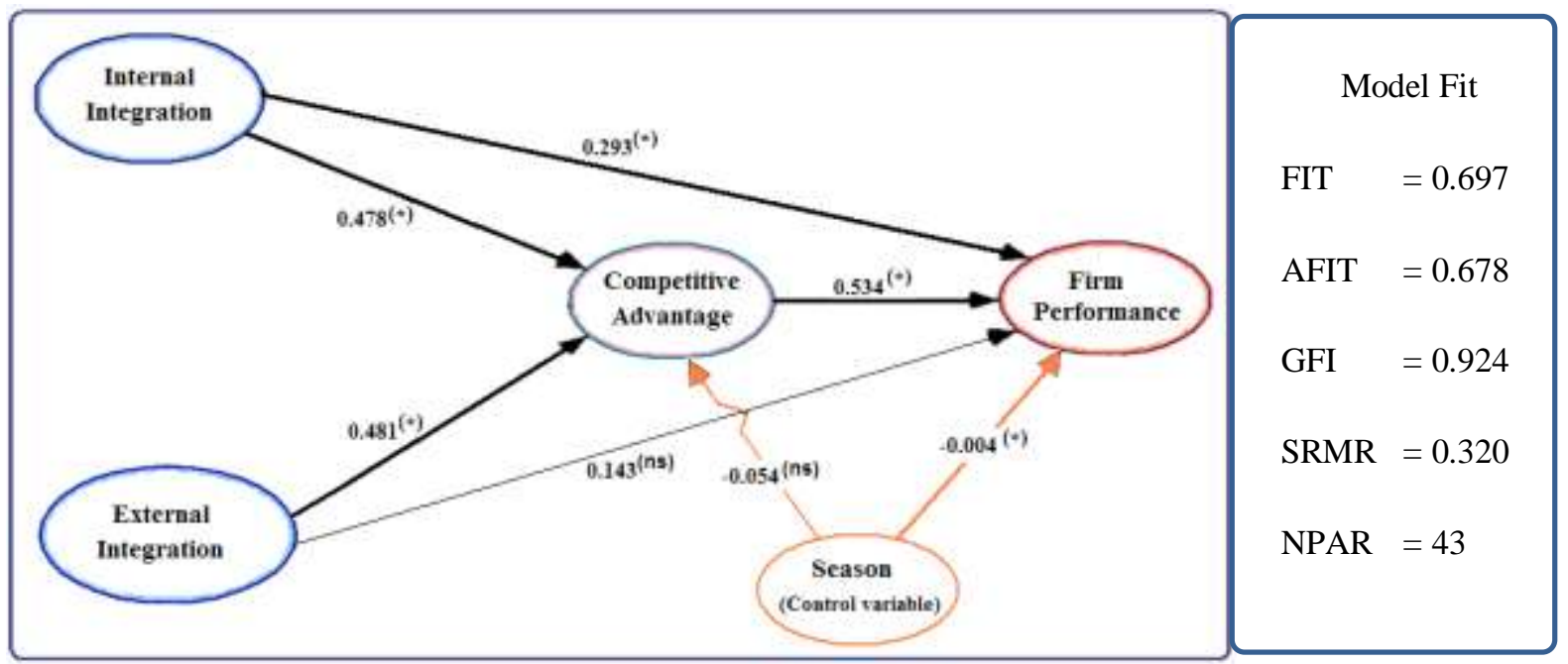

Note: $\mathrm{ns}=$ non significant, $\mathrm{CR}^{*}=$ significant at $\alpha=.05$.

Figure 2. Diagram for hypothesis testing and path coefficient for GSCA

The goodness of fit of the structural model and overall model shows that the model specified in this research can explain $69.70 \%$ of the variance of the corrected data (adjusted FIT). Also, the value of GFI $=0.924$ and SRMR $=0.320$ shows that the model has sufficient fit since recommended GFI is $\geq 0.90$ and SRMR is considered to be better when it is closer to zero. The result of the tests for the direct influence among variables in this research is presented fully in Table 2.

Table 2. Hypothesis testing and path coefficient for GSCA

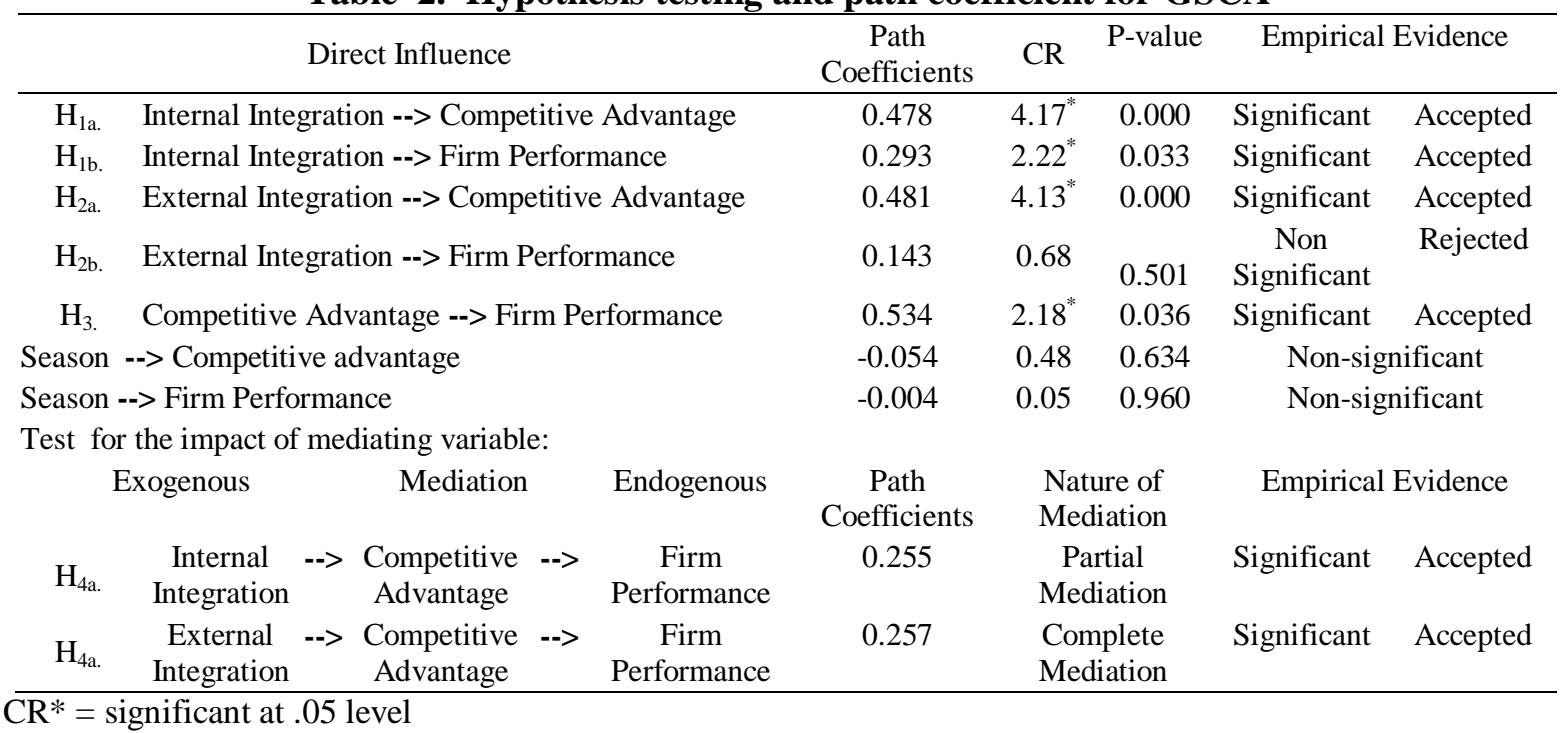


Figure 2 and Table 2 show that of the nine direct influence from the tested variables, there are four with significant impact, that is: internal integration has significant impact on competitive advantage and firm performance; external integration has significant impact on competitive advantage; competitive advantage has significant impact on firm performance. External integration does not have significant impact on firm performance. The test of coefficient for the seasonal variables as control finds that it has negative and insignificant impact on competitive advantage and firm performance. Test on the impact of mediation aims to detect the intervening variable in the model through the differences in coefficients using an examination method. The test result of path coefficient and hypotheses for the impact of mediation variable in Table 2 shows that the impact of internal integration on firm performance through competitive advantage is partial mediation. This means that the relation between internal integration can directly impact performance and can also do so through the mediation of competitive advantage. Further, competitive advantage is influenced by external integration and competitive advantage which significantly impact the firm performance. However, external integration does not have direct significant impact on firm performance so that competitive advantage can be said to be a complete mediation variable. This means that the external integration does not have direct influence on firm performance, but can only influence firm performance significantly through the mediation of competitive advantage.

\section{Discussion}

The results obtained by analyzing the internal supply chain integration on the competitive advantage and firm performance show a positive and significant impact. The test results indicate that there is enough empirical evidence to accept $\left(\mathrm{H}_{1 \mathrm{a}}\right.$ and $\left.\mathrm{H}_{1 \mathrm{~b}}\right)$ which states that internal integration significantly enhances the competitive advantage and firm performance. The result of hypothesis testing shows that internal integration has positive and significant impact on competitiveness. Therefore, the result of this research has proven that better implementation of internal integration would increase competitiveness and performance of fishery companies. The result of this research is consistent with the theory from [15] that well-integrated SCM implementation, both internally and externally, would create strategic opportunity for achieving competitiveness. The result of this research is also consistent with the findings of $[2,7,11,26]$ that internal integration is capable of improving competitiveness and firm performance. The high level implementation of internal integration can improve company performance, and this supports the findings of $[1,10,25]$. The result of hypothesis testing $\left(\mathrm{H}_{2 \mathrm{a}}\right)$ shows that external integration of supply chain has positive and significant impact on competitiveness. This is supported by the fact that good external integration would increase competitiveness. This finding supports the theories from $[15,22,38]$ that external integration in relation to integration of database application among business partners. This finding supports the research by [7,11] that external integration of supply chain as reflected through external cooperation and coordination is capable of increasing competitiveness.

The result of analysis shows that external integration does not have significant impact on firm performance. The result of tests shows that it cannot prove the expected relation and therefore hypothesis $\left(\mathrm{H}_{2 \mathrm{~b}}\right)$ is hereby rejected. It is evident that implementation of external integration as measured from the relations of external cooperation, coordination and collaboration between the company and its business partners (including supplier and customer) has not made meaningful contribution to the achievement of firm performance. This indicates that external coordination is more dominant in reflecting external integration, but it has not been implemented well. Therefore, this is one of the causes that prevent external integration to supplier and customer does not have real impact on performance improvement. This also occurs due to differences and conflict of goals among the actors involved. On the other hand, the company requires high level of flexibility by changing the number, specification and schedule of the fish delivery.

The result of this research supports the findings that external integration to the supplier [3] and external integration to customer [1] do not have significant impact on company performance. The findings of this research supports the proposition from $[11,12]$ that the challenge in the integration of supply chain comes from the supply chain network. The primary problem in the implementation of integrative SCM is the difficulties in creating harmonious coordination and relation with other parties, mutual suspicion and cultural differences. The result of this research does not support $[7,11,16]$, which state that the company which has reached high level of external integration to supply chain can improve performance. The difference in the research findings is caused by the characteristics of the products being studied, where most of previous studies examined manufacturing industry with durable products and little product variation, while our research is carried out on fishery companies where the input is of much less durability, very seasonal and has large variation in product sizes.

Competitiveness has positive and significant impact on performance. Test result shows that there is enough evidence to accept hypothesis $\mathrm{H}_{3}$, which states that high competitiveness can improve company performance. This means that higher competitiveness would result in increase performance. Therefore, the variable of competitiveness can explain the variance of fishery companies performance. This supports [14] that improvement of competitiveness and performance can be carried out through the improvement of quality 
continuously for all business activities which are focused in customers. Our findings support the theory of competitiveness [5,26] which states that competition is the core/essence of company success and failure and would determine the appropriateness of company activities which can support company performance. Based on competence approach, competitiveness comes from strategy, structure, competence, innovation and tangible and intangible resources. Our findings support the theory from [15] that quality is not only an important element in operation but also the key for company success in operating. Our findings also supports the theory of [14] that high quality of performance is very important for the success of operation and firm performance. The results of our research is consistent with the previous studies $[2,7,11,18,39]$ that high competitiveness can directly improve company performance. This research was carried out on big-scale fishery companies and therefore our findings support [2] which states that competitive capacity does not bring significant effect on the performance of small companies. However, our findings is different from [25] which states that there are no significant relation between competitive priority and supply chain performance for low performance companies.

The result of coefficient test for the impact of control variable of season on competitiveness and performance shows that season has negative impact on performance and competitiveness. This shows that higher impact of season would result in reduction of competitiveness and performance for fishery companies. Our findings confirms [15] which states that season is regular movement either up or down which can reduce productivity and competitiveness. Our findings is also consistent with [40] that the impact of season has reduced the ability of the fishermen to predict the correct time and location to catch fish since the climate pattern has changed. This results in a reduction in fish supply to the fishery companies.

Path analysis for the impact of internal integration on performance, which is mediated by competitiveness, shows a positive and significant coefficient and this is enough evidence to accept $\mathrm{H}_{4 \mathrm{a}}$. This means that competitiveness is really influenced by internal integration to supply chain and competitiveness has significant impact on performance, and then internal integration has an impact on performance. It can be concluded that improvement of the implementation for internal integration will have direct impact for the increasing performance for the company and the same effect can flow through high level of competitiveness. The result of mediation test shows that competitiveness has a partial mediation effect.

This findings are empirical evidence that competitiveness is an intervening variable which mediates the relation between implementation of internal integration to supply chain on performance partially. This lends support to the theory of supply chain integration [14] that the effective coordination, cooperation and collaboration can improve competitiveness and in the end can improve firm performance. This findings also supports the proposition from [1,42] that in contingency perspective, competitiveness as mediation variable is capable of exerting real influence on the relation of internal integration to supply chain on firm performance. Our findings also support the propositions from [27] which states that integration of supply chain, both internal and external, can improve company performance but through competitiveness. High level of competitive advantage would directly increase firm performance.

The path coefficient for the impact of external integration to performance, which is mediated by competitiveness, has positive and significant value. This is sufficient proof to accept $\mathrm{H}_{4 \mathrm{~b}}$, which states that external integration does not have significant impact on performance but only through competitiveness. It can be concluded that implementation of high level of external integration does not have significant impact on the improvement of performance but only through the mediation of competitiveness where the significant impact can result in the increase in firm performance. Therefore, competitiveness works as a complete mediation between the external integration and performance. This is consistent with [22,28] that integration along the supply chain is the basis for improving performance and this comes from a competitiveness which must be developed through integration to the supplier, companies and customers. Based on tests on mediation to competitiveness, it was found that the impact of internal integration on performance, as mediated by competitiveness, has the greatest value for path coefficient compared to external integration. This shows that internal integration has a contribution or has dominant role for performance, mediated through competitiveness.

\section{Implication and Originality Research}

The result of this research is expected to gain more insight for the theory of SCM [14,15,20,22,38, 41,42] which sees that SCM implementation based on the philosophy of integration can improve competitiveness and in the end can support company performance. The findings of this research is consistent with several studies $[1,2,7,11,16,26,31]$, that implementation of good internal integration and external integration can improve competitiveness and performance of the company. High level of competitiveness is then capable of increasing company performance, and this supports the findings of $[2,7,11,18,39]$. This research can prove the importance of the relation among business partners in applying the concept of integrative SCM. Business partners are important for the company. The primary factor for company success in the implementation of integrative SCM is through good coordination, collaboration and cooperation with business partner so that the relation can be advantageous in the long run. 
This article also contributes to the development of conceptual and theoretical perspectives concerning the implementation of integrative SCM in the effort to improve competitiveness and performance for manufacturing industry (fishery companies) which is based on the theory of operational management and SCM integration. The empirical findings of this research contributes to the theory of SCM by exploring a model for the structural relation between the implementation of internal and external integration both directly and through the mediation of competitiveness, where it was found to have significant impact on the performance of fishery companies. Lastly, this research provides a different perspective by discovering season as control variable which does not contribute to the improvement of competitiveness and performance of companies.

The practical contribution of this research is expected to provide managerial implications for the implementation of integrative SCM on the improvement of competitiveness and performance of fishery companies. The implementation of integrative SCM is not limited only to coordination and cooperation, both internal and external, with the supplier and customer, but also includes collaboration in the form of sharing ideas and information, harmonizing incentives and synchronizing decisions in the company and with external partners to the supplier and customer. The findings of this research also provide managerial knowledge and insight concerning the importance of SCM integrated manner by observing the ability of supply chain partner in responding to the changes in market demand in order to maintain competitive advantage and performance. Director or managers of fishery companies are the leaders of the organization and in the upcoming future they have to drive the implementation of integrative SCM. Effective leadership is not only focused on communicating the importance of SCM to the supplier and customer and other business partner but also to express the goals and philosophy of SCM to the employees. This research is expected to provide contribution for the fishery industry in the implementation of integrative SCM for the improvement of competitiveness and performance of companies. Consideration on seasonal variation is also important in anticipating the demand for fish supply so as to maintain the flow of production.

The findings of this research can be used as the basis for the configuration of the development of models for the relation between the implementation of integrative SCM and season on competitiveness and performance of company, both direct and through the mediation of competitiveness in the GSCA models. Test result can provide empirical evidence that the mediation role of competitiveness has significant impact on company performance. Based on the propositions of the literature review $[6,21]$ which state that collaboration is the key of supply chain integration, the result of our research has shown by developing measurement model by including indicators of collaboration, which are more dominant or perceived as the most important in the implementation of internal integration and external integration of supply chain. The last finding is that seasonal variation has a substantial impact on the competitive advantage and performance of fishery companies.

\section{Conclusion and Limitations Research}

Good implementation of internal integration to supply chain can improve competitive advantage and performance of fishery companies. Good internal coordination, cooperation and collaboration has an important role in supporting the implementation of integrative SCM. The implementation of external integration supply chain to the suppliers and customers would be very influential towards the improvement of competitive advantage and performance, however the contribution for performance is not yet significant. This research has found the important role of competitiveness as the mediator for the relation between implementation of integrative SCM in the effort to support the improvement of fishery companies' performance in Southeast Sulawesi. Internal integration supply chain has a dominant role indicator contribution for company performance as mediated by competitive advantage. Seasonal variation is one of the causes for the low competitive advantage and performance for fishery companies.

There are several limitations of this research, especially in terms of its research object, which is limited only to fishery companies in Southeast Sulawesi using the directors or managers as respondents. This limits the generalizability of the research findings only for manufacture industry, especially fishery sector within the same region. Further studies on integrative SCM should involve the suppliers, customer and business partners of the company. Then, the empirical analysis based on survey data here is still limited to cross-sectional relations, and therefore further studies need to be conducted with longitudinal flow up design to enable such study to re-test whether the relations among analyzed variables in the research have changed or not.

The accuracy for the model of this study is 0.697 . This means that $69.70 \%$ of the variance in the variable of internal and external integration supply chain, competitive advantage, seasonal and performance can be explained by the model and the remaining $30.30 \%$ is explained by other variables. Therefore, further studies in the future can develop a research model by adding other variables such as: structure of supply chain, integrated information (IT), and culture of quality. The regional government should be more proactive in dealing with the existence of fishery companies in Southeast Sulawesi as one of the components of the supply chain in making use of existing facilities to regulate private fishermen, unloading and auction of fish. Improvement and procurement of infrastructure is necessary for improving competitive advantage and performance. 


\section{References}

[1] Sakun Boon-itt and Chee Yew Wong, The moderating effects of technological and demand uncertainties on the relationship between supply chain integration and customer delivery performance. International Journal of Physical Distribution and Logistics Management, 41(3), 2011, 253-276

[2] Soo Wook Kim, Effects of supply chain management practices, integration and competition capability on performance. Supply Chain Management: An International Journal, 11(3), 2006, 241-248

[3] Pamela Danese and Pietro Romano, Supply Chain Integration And Efficiency Performance: A Study On The Interactions Between Customer And Supplier Integration, Supply Chain Management: An International Journal, 16(4), 2011, 220-230

[4] Van Der Vaart, T. and Van Donk, D.P., A critical review of survey-based research in supply chain integration, International Journal of Production Economics, 111(1), 2008, 42-55.

[5] Michael Porter, Competitive Advantage Menciptakan dan Mempertahankan Kinerja Unggul, (Terjemahan Tim Penerbit Karisma Publishing Group. Jakarta 2008).

[6] Frank Wiengarten; Brian Fynes and Alan McKittrick, Collaborative Supply Chain Practices and Performance: Exploring The Key Role Of Information Quality. Supply Chain Management: An International Journal 15(6), 2010, 463-473

[7] Gimenez, C.and Ventura, E., Logistic-Production, Logistic-Marketing and External Integration Their Impact on Performance, Emerald International Journal of Operations \& Production Management , 25(1), 2005, 20-38

[8] Romano, P., How can fluid dynamics help supply chain management?, International Journal of Production Economics, 118(2), 2009, 463-72.

[9] Fynes, B., de Burca, S. and Voss, C., Supply chain relationship quality, the competitive environment and performance, International Journal of Production Research, 43(16), 2005, 03-20.

[10] Jiqin Han Nanjing J.H.T. and S.W.F. Omta, Integrated information and logistics management, quality management and firm performance of pork processing industry in China. British Food Journal, 111(1), 2009, 9-25

[11] Gimenez, C. and Ventura, E., Supply Chain Management as a competitive advantage in the Spanish grocery sector, International Journal of Logistics Management. 14(1), 2003, 77-88

[12] Hussain A.H Awad and Mohammad Othman Nassar, Supply Chain Integration: Definition and Challenges. Proceedings of the IMECS, 1(1), 2010, 1-5.

[13] R. Glenn Richey Jr; Haozhe Chen; Rahul Upreti and Frank G. Adams, The moderating role of barriers on the relationship between drivers to supply chain integration and firm performance. International Journal of Physical Distribution \& Logistics Management, 39(10), 2009, 1-14

[14] Krawjeski, Rizmant dan Malhotra, Operation Managemen, Processes and Supply Chain, (Ninth Edition, Pearson, 2010).

[15] Heizer. J and Render B, Operations Management (Manajemen Operasi), (Jilid 1 dan 2, Penerbit Salemba Empat. Jakarta, 2010).

[16] Vijay R. Kannan and Keah Choon Tan, Supply chain integration: cluster analysis of the impact of span of integration, Supply Chain Management: An International Journal 15(3), 2010, 207-215

[17] Gustavo Vargas, Lily Cardenas and JoseÂ Luis Matarranz, Internal and external integration of assembly manufacturing activities. International Journal of Operations \& Production Management, 20(7), 2000, 809-822.

[18] Li, S.H., Rao, S.S., Nathan, R.T. and Nathan, B.R., The impact of supply chain management practices on competitive advantage and organizational performance", Omega, 34(1), 2006, 107-24.

[19] Lee, C.W., Kwon, I.G. and Severance, D., Relationships between supply chain performance and degree of linkage among supplier, internal integration and customer, Supply Chain Management: An International Journal, 12(6), 2007, 444-52.

[20] Cooper, M.C; Ellram, L.M; Gardner \& Hanks, A, Meshing Multiple Alliances, Journal of Business Logistics, 18(1), 1997, 50-68.

[21] Lejeune M.A and Yakova, N., On characterizing the 4C's in supply chain management. Journal of Operation Management, 23(1). 2005, $81-100$

[22] Lina Anatan dan Lena Elitan, Supply Chain Management Teori dan Aplikasi, (Penerbit Alfabeta, Bandung, 2008).

[23] Flynn, B.B., Huo, B. and Zhao, X., The impact of supply chain integration on performance: a contingency and configuration approach, Journal of Operations Management, 28(1), 2010, 58-71.

[24] Stevens S. Integrating the supply chain, International Journal of Physical Distribution \& Material Management, 19(8), 1989, 3-8.

[25] Chin S. Ou; Fang C. Liu; C. Yu Hung; and David C. Yen, A Structural Model of Supply Chain Management on Firm Performance. International Journal of Operations \& Production Management. 30(5), 2010, 526-545.

[26] David Xiaosong Peng; Roger G. Schroeder and Rachna Shah, Competitive priorities, plant improvement and innovation capabilities, and operational performance A test of two forms of fit, International Journal of Operations \& Production Management, 31(5), 2011, 484-510

[27] Ting Chi; Peter P.D. Kilduff and Vidyaranya B. Gargeya, Alignment Between Business Environment Characteristics, Competitive Priorities, Supply Chain Structures, and Firm Usiness Performance. International Journal of Productivity and Performance Management, 58(7), 2009, 645-669.

[28] Towill D.R. and P. Childerhouse, Industrial engineering priorities for improved demand chain performance. International Journal of Productivity and Performance Management, 60(3), 2011, 202-221

[29] Kuncoro, Mudrajad, Metode riset Untuk bisnis dan Ekonomi, Bagaimana menulis tesis? (Erlangga, Surabaya, 2003)

[30] DKP, Laporan Tahunan PPS Kendari Tahun 2010, (Direktorat Perikanan Tangkap Kendari, 2011)

[31] Tracey and Vonderembse, Building Supply Chain: A Key To Enhancing Manufacturing Performance, Journal of Business American, 15(1), 2004, 10-20.

[32] BPS, Sulawesi Tenggara Dalam Angka, (Badan Pusat Statistik, Kendari 2011)

[33] Heungsun Hwang, Malhotra, Youngchan Kim, Marc A. Tomiuk, and Sungjin Hong, A Comparative Study on Parameter Recovery of Three Approaches to Structural Equation Modeling. Journal of Marketing Research, XLVII, 2010, 699-712

[34] Solimun, Pemodelan Generalized Structured Component Analysis (GeSCA). (Program Studi Statistika FMIPA, PDIM FE Universitas Brawijaya, 2012).

[35] Cooper, D. R., and Schindler, P. S., Business Research Methods. (Eight Edition. McGraw-Hill/Irwin, New York, NY 10020, 2003)

[36] Malhorta, Naresh, Marketing Research, An Applid Orientantion. (Prentice-Hall. Inc., New Jersey. 2010).

[37] Hair, Joseph F, William C. Black, Barry J. Babin, and Ronald L. Tatham, Multivariate Data Analysis. (Siventh Edition. Pearson Education, 2010)

[38] Pujawan, Supply Chain Management. (Penerbit Guna Widya, Surabaya, 2005)

[39] Rajesh Rajaguru and Margaret Jekanyika Matanda, Influence of inter-organisational integration on business performance The mediating role of organizational-level supply chain functions. Journal of Enterprise Information Management, 22(4), 2009, 456-467

[40] Khalik Abdul, Climate Changde already hitting RI's poores, (Jakarta Post, Jakarta, 2007). 
[41] Arni Halldorsson; Herbert Kotzab, Juliana H. Mikkola and Tage Skjøtt-Larsen, Complementary theories to supply chain management. Supply Chain Management: An International Journal, 12(4), 2007, 284-296

[42] Danese, P., Towards, A contingency theory of collaborative planning initiatives, International Journal of Production Research, 49(4), 2011, 81-103.

[43] Soeryanto Eddy, Manajemen Kinerja Falsafah, Konsep \& Aplikasinya, (Universitas Komputer Indonesia, Jakarta 2010)

[44] Pagell, M. and Krause, D.R., Re-exploring the relationship between flexibility and the external environment, Journal of Operations Management, 21(1), 2004, 629-49.

Appendix I. Validity and reliability test of measures (result SPSS)

\begin{tabular}{|c|c|c|c|}
\hline $\begin{array}{l}\text { Constructs/ } \\
\text { Indicators }\end{array}$ & Item & $\begin{array}{l}\text { Coefficients } \\
\text { Correlation }\end{array}$ & $\begin{array}{c}\text { Cronbac } \\
\text { h's } \\
\text { Alpha } \\
\end{array}$ \\
\hline \multicolumn{4}{|c|}{ Internal Integration (II): } \\
\hline $\mathrm{II}_{1}$. Internal & $\mathrm{II}_{11}$. cross-functional informal working team coordination & 0.897 & \multirow{3}{*}{0.788} \\
\hline \multirow[t]{2}{*}{ Coordination } & $\mathrm{II}_{12}$. Implementation of cross-functional idea sharing & 0.905 & \\
\hline & $\mathrm{II}_{13}$. Synergetic cross-functional team & 0.702 & \\
\hline $\mathrm{II}_{2}$. Internal & $\mathrm{II}_{21}$. Cooperation in integrated planning & 0.840 & \multirow{3}{*}{0.796} \\
\hline \multirow[t]{2}{*}{ Cooperation } & $\mathrm{II}_{22}$. Determining mutual goal & 0.796 & \\
\hline & $\mathrm{II}_{23}$. Building a common understanding & 0.892 & \\
\hline $\mathrm{II}_{3}$. Internal & $\mathrm{II}_{31}$. Information sharing across & 0.782 & \multirow[t]{3}{*}{0.624} \\
\hline \multirow[t]{2}{*}{ Collaboration } & $\mathrm{II}_{32}$. Harmonious incentive across-functions & 0.808 & \\
\hline & $\mathrm{II}_{33}$. Synchronized decision across-function & 0.674 & \\
\hline \multicolumn{4}{|c|}{ External Integration (EI): } \\
\hline $\mathrm{EI}_{1 .}$ External & $\mathrm{EI}_{11 .}$ Supplier informal task force coordination & 0.890 & \multirow{3}{*}{0.651} \\
\hline \multirow[t]{2}{*}{ Coordination } & $\mathrm{EI}_{11}$. Sharing ideas with suppliers & 0.779 & \\
\hline & $\mathrm{EI}_{11}$. Cooperative customers and informal working team & 0.611 & \\
\hline $\mathrm{EI}_{2 .}$ External & $\mathrm{EI}_{21}$. Integrated planning cooperation & 0.914 & \\
\hline \multirow[t]{2}{*}{ Cooperation } & $\mathrm{EI}_{22 .}$. Determining mutual goal with supplier & 0.866 & \multirow{3}{*}{0.885} \\
\hline & $\mathrm{EI}_{23}$. Building a common understanding supplier & 0.926 & \\
\hline $\mathrm{EI}_{3}$. External & $\mathrm{EI}_{31 .}$ Information sharing with suppliers & 0.898 & \\
\hline \multirow[t]{2}{*}{ Collaboration } & $\mathrm{EI}_{32 .}$ Customers incentive Alignment & 0.739 & \multirow{3}{*}{0.691} \\
\hline & $\mathrm{EI}_{33}$. Synchronized decision with suppliers & 0.710 & \\
\hline \multicolumn{3}{|c|}{ Competitive Advantage (CA): } & \\
\hline $\mathrm{CA}_{1}$. Pricing & $\begin{array}{l}\mathrm{CA}_{1} \text {. The company's offered price suit the customers need more than } \\
\text { competitors price. }\end{array}$ & 0.680 & \multirow{6}{*}{0.804} \\
\hline $\mathrm{CA}_{2}$. Quality & $\mathrm{CA}_{2}$. The company provides better product quality than competitors & 0.831 & \\
\hline $\mathrm{CA}_{3}$. Reliability & $\mathrm{CA}_{3}$. The company provides product delivery than competitors & 0.772 & \\
\hline $\mathrm{CA}_{4}$. Innovation & $\mathrm{CA}_{4}$. T he company provides more Innovative than competitors & 0.711 & \\
\hline $\begin{array}{l}\mathrm{CA}_{5} . \text { Time to } \\
\text { market }\end{array}$ & $\begin{array}{l}\mathrm{CA}_{5} \text {. The company provides more timely market provision than } \\
\text { competitors. }\end{array}$ & 0.655 & \\
\hline $\begin{array}{l}\mathrm{CA}_{6} . \text { Post-sales } \\
\text { services }\end{array}$ & $\begin{array}{l}\mathrm{CA}_{6} \text {. The company provides better after-sales services than } \\
\text { competitors }\end{array}$ & 0.603 & \\
\hline \multicolumn{4}{|c|}{ Firm Performance (FP): } \\
\hline \multirow[t]{3}{*}{$\mathrm{FP}_{1}$. Cost } & $\mathrm{FP}_{11}$. Ability to reduce suppliers' service upkeep & 0.850 & \multirow[t]{3}{*}{0.785} \\
\hline & $\mathrm{FP}_{12}$. Reducing transportation cost for customer & 0.848 & \\
\hline & $\mathrm{FP}_{13}$. Ability to lower the delivery processing cost. & 0.811 & \\
\hline \multirow[t]{2}{*}{$\mathrm{FP}_{2}$. Lead-time } & $\mathrm{FP}_{21}$. Supply shortage cost reduction in production from supplier & 0.948 & \multirow[t]{2}{*}{0.865} \\
\hline & $\mathrm{FP}_{22}$. Supply shortage cost reduction in production to customers & 0.932 & \\
\hline \multirow[t]{2}{*}{$\mathrm{FP}_{3}$. Stock-out } & $\mathrm{FP}_{31}$. Reducing the delay for either fish purchase from supplier & 0.877 & \multirow[t]{2}{*}{0.755} \\
\hline & $\mathrm{FP}_{32}$. Reducing the delay for either fish delivery to customer & 0.920 & \\
\hline \multicolumn{4}{|c|}{ Season (S/control variable): } \\
\hline$S_{1}$. Quantity & $\begin{array}{l}S_{1} \text {. Fish supply quantity requirement decrease caused by } \\
\text { climate/climate }\end{array}$ & 0.985 & 0.971 \\
\hline$S_{2}$. Quality & $\mathrm{S}_{1}$. Fish supply quality decrease caused by weather/climate & 0.958 & \\
\hline $\mathrm{S}_{3}$. Time delivery & $S_{1}$. Fish supply delivery latency caused by weather/climate & 0.974 & \\
\hline
\end{tabular}

Note: Coefficients Correlation $>0,30$ or significant at $\alpha=.05$ (Valid) and Cronbach's Alpha > .70 (Reliabel) 
Appendix II. Data processing result GSCA

Measurement Model

\begin{tabular}{|c|c|}
\hline \multicolumn{2}{|c|}{ Model Fit } \\
\hline FIT & 0.697 \\
\hline AFIT & 0.678 \\
\hline GFI & 0.924 \\
\hline SRMR & 0.320 \\
\hline NPAR & 43 \\
\hline
\end{tabular}

\begin{tabular}{|c|c|c|c|c|c|c|c|c|c|}
\hline \multirow[t]{2}{*}{ Variable } & \multicolumn{3}{|c|}{ Loading } & \multicolumn{3}{|c|}{ Weight } & \multicolumn{3}{|c|}{ SMC } \\
\hline & Estimate & SE & $\mathrm{CR}$ & Estimate & SE & $\mathrm{CR}$ & Estimate & SE & $\mathrm{CR}$ \\
\hline Internal Integration & \multicolumn{9}{|c|}{$\mathrm{AVE}=0.837$, Alpha $=0.898$} \\
\hline II.1 & 0.920 & 0.038 & $24.03^{*}$ & 0.366 & 0.020 & $18.04^{*}$ & 0.847 & 0.068 & $12.53^{*}$ \\
\hline II. 2 & 0.909 & 0.038 & $23.75^{*}$ & 0.365 & 0.020 & $18.12^{*}$ & 0.826 & 0.068 & $12.09^{*}$ \\
\hline II.3 & 0.916 & 0.041 & $22.58^{*}$ & 0.362 & 0.024 & $15.23^{*}$ & 0.839 & 0.071 & $11.82^{*}$ \\
\hline External Integration & \multicolumn{9}{|c|}{ AVE $=0.808$, Alpha $=0.877$} \\
\hline EI.1 & 0.914 & 0.027 & $33.76^{*}$ & 0.386 & 0.035 & $10.96^{*}$ & 0.836 & 0.049 & $17.1^{*}$ \\
\hline EI.2 & 0.889 & 0.052 & $17.11^{*}$ & 0.367 & 0.020 & $18.2^{*}$ & 0.790 & 0.087 & $9.11^{*}$ \\
\hline EI.3 & 0.893 & 0.054 & $16.45^{*}$ & 0.360 & 0.017 & $21.6^{*}$ & 0.797 & 0.092 & $8.69^{*}$ \\
\hline Competitive Advantage & \multicolumn{9}{|c|}{ AVE $=0.671$, Alpha $=0.901$} \\
\hline CA.1 & 0.842 & 0.059 & $14.27^{*}$ & 0.230 & 0.034 & $6.86^{*}$ & 0.709 & 0.099 & $7.18^{*}$ \\
\hline CA. 2 & 0.859 & 0.039 & $22.24^{*}$ & 0.208 & 0.032 & $6.57^{*}$ & 0.738 & 0.065 & $11.4^{*}$ \\
\hline CA.3 & 0.884 & 0.051 & $17.29^{*}$ & 0.197 & 0.031 & $6.37^{*}$ & 0.782 & 0.084 & $9.27^{*}$ \\
\hline CA.4 & 0.810 & 0.066 & $12.36^{*}$ & 0.209 & 0.023 & $9.13^{*}$ & 0.657 & 0.099 & $6.65^{*}$ \\
\hline CA.5 & 0.741 & 0.070 & $10.66^{*}$ & 0.168 & 0.035 & $4.76^{*}$ & 0.550 & 0.101 & $5.42^{*}$ \\
\hline CA.6 & 0.768 & 0.090 & $8.58^{*}$ & 0.207 & 0.020 & $10.5^{*}$ & 0.590 & 0.124 & $4.76^{*}$ \\
\hline Firm Performance & \multicolumn{9}{|c|}{$\mathrm{AVE}=0.786$, Alpha $=0.862$} \\
\hline FP.1 & 0.890 & 0.038 & $23.56^{*}$ & 0.387 & 0.031 & $12.31^{*}$ & 0.792 & 0.065 & $12.09^{*}$ \\
\hline FP.2 & 0.867 & 0.054 & $15.91^{*}$ & 0.345 & 0.025 & $13.73^{*}$ & 0.751 & 0.091 & $8.27^{*}$ \\
\hline FP.3 & 0.902 & 0.047 & $19.11^{*}$ & 0.396 & 0.029 & $13.42^{*}$ & 0.814 & 0.083 & $9.86^{*}$ \\
\hline Season & \multicolumn{9}{|c|}{$\mathrm{AVE}=0.950$, Alpha $=0.974$} \\
\hline S.1 & 0.981 & 0.005 & $187.35^{*}$ & 0.341 & 0.015 & $23.22^{*}$ & 0.963 & 0.010 & $93.82^{*}$ \\
\hline S.2 & 0.963 & 0.008 & $119.21^{*}$ & 0.339 & 0.005 & $62.84^{*}$ & 0.927 & 0.016 & $59.5^{*}$ \\
\hline S.3 & 0.980 & 0.006 & $171.79^{*}$ & 0.346 & 0.011 & $30.62^{*}$ & 0.960 & 0.011 & $85.97^{*}$ \\
\hline
\end{tabular}

$\mathrm{CR}^{*}=$ significant at .05 level

Structural Model

\begin{tabular}{|c|c|c|c|c|}
\hline \multicolumn{5}{|c|}{ Path Coefficients } \\
\hline & Estimate & SE & $\mathrm{CR}$ & P-Value \\
\hline Internal Integration -> Competitive Advantage & 0.478 & 0.115 & $4.17^{*}$ & 0.000 \\
\hline Internal Integration -> Firm Performance & 0.293 & 0.132 & $2.22^{*}$ & 0.033 \\
\hline External Integration -> Competitive Advantage & 0.481 & 0.116 & $4.13^{*}$ & 0.000 \\
\hline External Integration -> Firm Performance & 0.143 & 0.212 & 0.68 & 0.501 \\
\hline Competitive Advantage -> Firm Performance & 0.534 & 0.244 & $2.18^{*}$ & 0.036 \\
\hline Season -> Competitive Advantage & -0.054 & 0.113 & 0.48 & 0.634 \\
\hline Season -> Firm Performance & -0.004 & 0.082 & 0.05 & 0.960 \\
\hline
\end{tabular}

$\mathrm{CR}^{*}=$ significant at .05 level

\begin{tabular}{|c|c|}
\hline \multicolumn{2}{|c|}{ R square of Latent Variable } \\
\hline Internal Integration & 0 \\
\hline External Integration & 0 \\
\hline Competitive Advantage & 0.938 \\
\hline Firm Performance & 0.915 \\
\hline Season & 0 \\
\hline
\end{tabular}




\begin{tabular}{|c|c|}
\hline \multicolumn{2}{|c|}{ Means Scores of Latent Variables } \\
\hline Internal Integration & 3.736 \\
\hline External Integration & 3.694 \\
\hline Competitive Advantage & 3.637 \\
\hline Firm Performance & 3.738 \\
\hline Season & 3.413 \\
\hline
\end{tabular}

\begin{tabular}{|l|c|c|c|c|c|}
\hline \multicolumn{7}{|c|}{ Correlations of Latent Variables (SE) } \\
\hline & $\begin{array}{c}\text { Internal } \\
\text { Integration }\end{array}$ & $\begin{array}{c}\text { External } \\
\text { Integration }\end{array}$ & $\begin{array}{c}\text { Competitive } \\
\text { Advantage }\end{array}$ & $\begin{array}{c}\text { Firm } \\
\text { Performance }\end{array}$ & Season \\
\hline Internal Integration & 1 & $0.919(0.039)^{*}$ & $0.947(0.021)^{*}$ & $0.933(0.035)^{*}$ & $-0.504(0.140)^{*}$ \\
\hline External Integration & $0.919(0.039)^{*}$ & 1 & $0.948(0.024)^{*}$ & $0.921(0.046)^{*}$ & $-0.520(0.114)^{*}$ \\
\hline Competitive Advantage & $0.947(0.021)^{*}$ & $0.948(0.024)^{*}$ & 1 & $0.950(0.021)^{*}$ & $-0.545(0.160)^{*}$ \\
\hline Firm Performance & $0.933(0.035)^{*}$ & $0.921(0.046)^{*}$ & $0.950(0.021)^{*}$ & 1 & $-0.517(0.134)^{*}$ \\
\hline Season & $-0.504(0.140)^{*}$ & $-0.520(0.114)^{*}$ & $-0.545(0.160)^{*}$ & $-0.517(0.134)^{*}$ & 1 \\
\hline
\end{tabular}

* significant at .05 level 